Wat zal mijn patiënt daarvan merken?

In onderzoeken wordt altijd gezocht naar de beste behandeloptie voor de patiënt, maar ook wordt gekeken naar de effectiviteit en doelmatigheid van een behandeling. Tegenwoordig is value based health care een belangrijke factor bij de keuze voor een behandeloptie. Het doel van dit onderzoek was om te kijken of de locator net zo goed presteert als de staafmesostructuur. Na 1 jaar blijkt dat de overkappingsprothese op een staafmesostructuur net iets beter presteert dan de overkappingsprothese op locators. Maar deze verschillen zijn heel erg klein. Verder onderzoek zou moeten uitwijzen of deze verschillen in de loop der tijd gelijk blijven of verder uit elkaar gaan lopen. Als de verschillen tussen beide opties zo minimaal blijven, zou (op basis van kosteneffectiviteit) de overkappingsprothese op locators op vier implantaten in de bovenkaak de voorkeur krijgen. Op dit moment kan nog niet hard gemaakt worden dat locators net zo goed presteren als een staafmesostructuur.

\section{Hoe moet eventueel vervolgonderzoek eruitzien?}

In dit onderzoek werden verschillende aspecten van een overkappingsprothese in de bovenkaak gedurende 1 jaar beoordeeld. Beide behandelopties bleken succesvol, met kleine, maar belangrijke, verschillen. 1 jaar is een relatief korte periode en daarom is het belangrijk de patiënten van deze studie langer te volgen om zo 5- of zelfs 10-jaarsresultaten te verkrijgen. Zo kunnen ook de verschillen in de nazorg voor beide systemen beoordeeld worden. Dit zou de conclusie kunnen veranderen en dit zou ook effect kunnen hebben op de maatschappelijke kostprijs en daarmee op de kosteneffectiviteit. Voor kosteneffectiviteitsstudies in de tandheelkunde ontbreken universele uitkomstmaten en willingness-to-pay-drempels. Het zou van toegevoegde waarde zijn als deze in de toekomst bepaald zouden worden.

In 2016 is er een nieuwe versie locators op de markt gekomen (Locator R-Tx). Deze tweedeversielocators zijn op verschillende punten veranderd. De vorm en de coating zijn anders; deze zouden effect kunnen hebben op het marginale botverlies. Ook kunnen deze locators gebruikt worden bij implantaten die tot $60^{\circ}$ convergent/divergent ten opzichte van elkaar staan. Een volgend onderzoek zou gebruik moeten maken van de nieuwe versie locators.

Naast het gebruik van een ander bevestigingssysteem kan ook klinisch en financieel voordeel behaald worden door het gebruik van minder implantaten. Een studie waarbij vier of twee implantaten gebruikt worden voor een overkappingsprothese in de bovenkaak is nog nooit gedaan en zou de mogelijkheden hiervoor moeten onderzoeken. Een overkappingsprothese op twee implantaten zou een voordeel kunnen zijn voor medisch gecompromitteerde patiënten die niet onder narcose kunnen voor een botaugmentatie. Het plaatsen van twee implantaten zou de postoperatieve morbiditeit kunnen verlagen waardoor een overkappingsprothese voor meer patiënten een behandeloptie zou zijn. Deze zou wel eerst beoordeeld moeten worden in een randomised controlled trial met relatief gezonde patiënten.

\title{
De Nationale Tandheelkunde Quiz
}

Het Nederlands Tijdschrift voor Tandheelkunde bestaat 125 jaar en viert dit op vrijdag 2 november vanaf 14.00 uur met de Nationale Tandheelkunde Quiz, onder leiding van Philip Freriks, in de grote televisiestudio 21 in Hilversum. Een uniek en eenmalig evenement voor tandheelkundig Nederland, waar de vier steden met mondzorgopleidingen het tegen elkaar opnemen. Vier? Ja, want ook de in 1987 gesloten Utrechtse faculteit Tandheelkunde doet mee.

De Quiz moet die dag antwoord geven op twee vragen: 'Wie is de slimste tandarts van Nederland?' En 'Welke tandheelkundefaculteit heeft de meeste tandheelkundige kennis?'

Om daarachter te komen worden er 's middags drie vragenrondes gehouden (over verleden, heden en toekomst) die worden ingeleid door respectievelijk Reina de Raat, Paul de Kok en Joerd van der Meer. Na elke inleiding krijgt Philip Freriks het woord en gaat de interactieve quiz van start, waaraan alle deelnemers meedoen. Allerlei soorten tandheel- kundige vragen komen voorbij, met een opzet die geïnspireerd is door het tv-programma De slimste mens. Veel vragen worden ingeleid door een video, foto of bijpassend attribuut. Rond de klok van 18.30 uur gaat de grote finale van start en een half uur later moet duidelijk zijn wie met de Slimste Tandarts Award en wie met de Slimste Faculteit Award naar huis gaat. De onafhankelijke jury bestaat uit leden met uiteraard een deskundige achtergrond op het gebied van de tandheelkunde: Casper Bots (voorzit-

ter), Tijmen Hiep, Marjolijn Oomens en Jack Plooij.

Hoofdsponsor van het evenement is de KNMT.

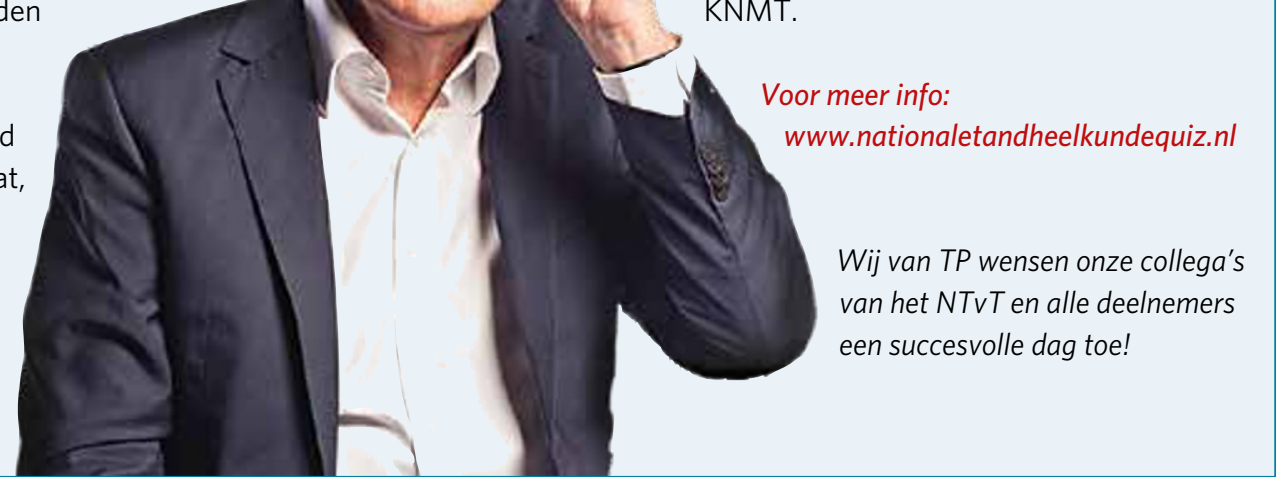

